\title{
The Effect of Maximum Physical Exertion Exercises According to The Anaerobic Threshold on The Development of Explosive Ability and The Skill of Shooting by Jumping High in Front of Handball for Youth
}

\author{
Hadeel Talib Mohammad, Prof.Dr. Suhad Qassem Al-Mousawi
}

DOI: $10.37648 /$ ijrssh.v10i04.034

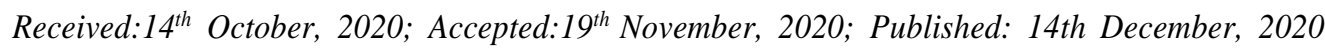

\section{ABSTRACT:}

The sports field is one of the fields that are concerned with the various methods and methods because of their positive impact on the development of actual training, the investment of the exerted effort in time, and through the follow-up of the researcher in the field and academic field, I noticed that there is a weakness in explosive ability, which affects performance and skill level during training and competition Therefore, the researcher decided to prepare maximum physical exertion exercises according to the anaerobic threshold as a principle of development in many physical and skill variables because good physical performance leads to reaching the best achievements and since the skill of shooting by jumping high - either constitutes a major role in achieving goals during the match that qualifies the team To win, therefore, the role of codified exercises was of great importance in acquiring this skill and mastering it to serve the nature of physical and technical performance and to determine the accuracy of correction towards the target, the aim of the research is to prepare and identify exercises the maximum physical effort according to the anaerobic threshold in developing the explosive ability and the skill of shooting by jumping high - in front of handball Youth, and the researcher adopted the experimental method by designing equal experimental and control groups The research community was determined and the research community was determined by handball players (Specialized School for Giftedness of the Ministry of Youth and Sports) of ages (17-18) years for the 2020 training season, which numbered 14 players, and the exercises were applied maximum physical effort according to the anaerobic threshold on the experimental group for a period of eight weeks With three training units per week, the researcher used the statistical bag (spss) to process the data, and the researcher reached the most important conclusions. The results were a remarkable development between pre and post measurement in developing the explosive ability and the skill of shooting by jumping high - in front of the handball youth for the experimental group and for the benefit of telemetry.

\section{INTRODUCTION}

The progress and development of various sciences and in the various human and scientific fields is an end in achieving and defining the basis for planning to reach the good and high level in the broad scientific community, yet there are efforts made by scientists and trainers in reaching the best methods, means and modern methods that are used to achieve new mathematical achievements by conducting Advanced scientific and practical studies and research with the various methods and methods regulated by the training load, to develop explosive power, and the handball contest 
is one of the competitions that many sports fans and followers are interested in, and it is a competition characterized by its instability in terms of repetition of movement, and therefore the athlete must possess healthy and efficient functional devices in order It bears the effort on it during the exercise of sports activity, hence the importance of research in trying to employ the role of sports training in terms of modern methods and methods through exercises of maximum physical effort according to the anaerobic threshold in developing the explosive ability and the skill of shooting by jumping high - in front of handball youth and due to the interference The big difference between the different mathematical sciences in order to improve the mathematical level and reach the touch Top twists.

Training according to the anaerobic threshold is one of the principles of development in many physical and skill variables because good physical performance leads to reaching the best achievements and since the skill of correction is a major role in achieving goals during the match that qualifies the team to win, so it was the role of exercises using maximum physical exercise exercises According to the anaerobic threshold is of great importance in acquiring this skill and mastering it, and through the follow-up of the researcher in the field and academic field, I noticed that there is a weakness in the explosive ability, which affects the performance and skill level during training and competition, so the researcher decided to prepare maximum physical effort exercises according to the anaerobic threshold According to the scientific foundations related to the components of the training load for this competition for the purpose of bringing about development in the level of this physical ability of the players and then trying to keep pace with the internationally advanced level in it.

:Research Objectives

- Identify the maximum physical exertion exercises according to the anaerobic threshold in developing explosive power and the skill of shooting by jumping high in front of handball youth.

- Preparing maximum physical exertion exercises according to the anaerobic threshold in developing explosive ability and the skill of shooting by jumping high in front of handball youth.

:Research hypotheses

- Exercises of maximum physical effort according to the anaerobic threshold have a positive effect on the development of explosive ability and the skill of shooting by jumping high - in front of handball youth.

:Research areas

- The human field: handball players, the Specialized School for Gifted People of the Ministry of Youth and Sports) for the 2020 sports season.

The temporal domain: for the period from 5/30/2020 to $5 / 8 / 2020$ -

- Spatial field: the closed hall for the specialized schools of handball of the Ministry of Youth and Sports / Baghdad governorate.

\section{MATERIALS AND METHODS:}

\section{Research Methodology:}

The researcher used the experimental method with the experimental design of the pre and post test for the two equivalent groups (experimental and control), due to its suitability to the nature of the research.

\section{Search community and sample:}

The research community was identified with the players of the handball competition, the handball players, the Specialized School for Giftedness of the Ministry of Youth and Sports (ages 17-18) for the 2020 training season, which totaled 14 players. The research sample was chosen in a comprehensive inventory method and the sample was divided into two groups (experimental and control) And by (7) players for each group Homogeneity and equivalence of the sample 
Table (1)

\begin{tabular}{|l|l|l|l|l|l|l|}
\hline $\begin{array}{l}\text { Coefficient of } \\
\text { torsion }\end{array}$ & $\begin{array}{l}\text { standard } \\
\text { deviation }\end{array}$ & Mediator & $\begin{array}{l}\text { Arithmetic } \\
\text { mean }\end{array}$ & $\begin{array}{l}\text { measruing } \\
\text { unit }\end{array}$ & Variables & sequence \\
\hline-0.612 & 0.041 & 1.73 & 1.70 & meter & Length & $\mathbf{1}$ \\
\hline-0.123 & 7.64 & 72.02 & 73.72 & Kg & Bloc & $\mathbf{2}$ \\
\hline-0.2351 & 0.86 & 19.03 & 19.40 & Year & Age & $\mathbf{3}$ \\
\hline$-0,541$ & 0,074 & 7,01 & 7,31 & Year & $\begin{array}{l}\text { Age of } \\
\text { training }\end{array}$ & $\mathbf{4}$ \\
\hline
\end{tabular}

Table (2)

It shows the arithmetic mean, standard deviations, the calculated (t) value, and the significance of the differences in the examined tests between the control and experimental groups in the pretest

\begin{tabular}{|c|c|c|c|c|c|c|c|c|}
\hline \multirow{2}{*}{$\begin{array}{l}\text { Indication of } \\
\text { differences }\end{array}$} & \multirow{2}{*}{$\begin{array}{l}\text { Indication } \\
\text { level }\end{array}$} & \multirow{2}{*}{$\begin{array}{l}\text { The computed } \\
\text { t value }\end{array}$} & \multicolumn{2}{|c|}{ Experimental group } & \multicolumn{2}{|c|}{ control group } & \multirow{2}{*}{$\begin{array}{l}\text { measruing } \\
\text { unit }\end{array}$} & \multirow[t]{2}{*}{ Variables } \\
\hline & & & $\begin{array}{l}\text { standard } \\
\text { deviation }\end{array}$ & $\begin{array}{l}\text { Arithmetic } \\
\text { mean }\end{array}$ & $\begin{array}{l}\text { standard } \\
\text { deviation }\end{array}$ & $\begin{array}{l}\text { Arithmetic } \\
\text { mean }\end{array}$ & & \\
\hline Not moral & 0,086 & 2,24 & 177,24 & 5,78 & 325,3 & 4,58 & $\mathrm{M} / \mathrm{cm}$ & $\begin{array}{l}\text { The explosive power } \\
\text { of the arms }\end{array}$ \\
\hline Not moral & 0,64 & 0,54 & 0,48 & 2,81 & $\mathbf{0 , 0 5}$ & 2.21 & $\mathrm{M} / \mathrm{cm}$ & $\begin{array}{l}\text { The explosive power } \\
\text { of the two men }\end{array}$ \\
\hline Not moral & $\mathbf{0 , 8 7}$ & 0,76 & 0,75 & 12,36 & 0,65 & 12,66 & Mmol / liter & $\begin{array}{l}\text { (LA) concentration } \\
\text { after effort }\end{array}$ \\
\hline Not moral & 0,63 & 0,65 & $\mathbf{0 , 8 7}$ & 5,81 & $\mathbf{0 , 7 6}$ & 4,69 & Watt / kg & $\begin{array}{l}\text { Clackogenic auxiliary } \\
\text { capacity }\end{array}$ \\
\hline Not moral & 0,56 & 0,54 & 0,61 & 5,64 & $\mathbf{0 , 4 8}$ & 4,71 & Degree & $\begin{array}{l}\text { Measure accuracy of } \\
\text { aiming from jumping } \\
\text { high - forward }\end{array}$ \\
\hline
\end{tabular}

*Significant below the degree of freedom (12) and the level of error 0.05

Means of gathering information, tools and devices used in research:

means of gathering information

Observation. Tests and measurements. And personal interviews -

:Devices Tools used in the research

:Devices and tools used in the research

$1 / 1$ - video camera at $180 \mathrm{p} / \mathrm{s}$

HP Korean laptop (1), CASIO handy electronic calculator- A legal handball court. 2 whistles, 12 medical balls, 12 tape measure tape to mark the stadium. (10) legal hand balls. Plastic cones of different sizes, count (30).
Field research procedures:

- The explosive strength test of the arms (a medicine ball $2 \mathrm{~kg}$ ) (Muhammad Hassan Allawi and Muhammad Nasreddin Radwan: 1994, p.84)

The purpose of the test: to measure the explosive force of the arms and from the sitting position.

- Required equipment: medicine ball ( $2 \mathrm{~kg})$, small rope, one chair, tape measure, chalk.

- Performance description: The laboratory sits on a chair, holding the medical ball with two hands, so that the ball is in front of the chest and below the level of the chin, and the torso must be adjacent to the back of the chair. The 
laboratory forward while pushing with the hands, and in order to limit the movement to pushing the ball with the hands only, gives the laboratory two consecutive attempts. Scoring: Each laboratory is given two attempts and the best attempt is scored.

Test the explosive strength of the leg muscles -

The purpose of the test: to measure the explosive force of the leg muscles Wide jump stability test:

The runner stands behind his marker line at the beginning of the jump pit so that the feet are equal, then the runner begins to jump forward towards the jump pit and land on both feet together. And he records the best distance achieved by the player from three attempts and to the nearest centimeter, so that the distance is measured to the nearest trace left by the runner.

- Measuring the concentration of lactic acid in the blood: (Hazaa Muhammad Hazaa: 1992, p. 556)

The aim of the test: To find out the level of lactic acid concentration in the blood after 5 minutes of the end of the effort

Used equipments:

Two devices were used (Lactate Pro LT - 1710) manufactured by the Japanese company (Arakray), a drill bit (2), a test strip (2), a calibration strip, count (2), Test strips, medical cotton, sterile materials, two small hand towels, registration form.

Performance description: After the tested player finishes playing a test, the level of lactic acid concentration in the blood is measured after the effort, that is, after performing the test at a time of (5) minutes, and this period is appropriate to ensure the transfer of lactic acid from the muscles to the blood, and the researcher followed the following steps to conduct the test:

Preparing the device to work by:

- Putting the check strip, then removing it

- Put the Calibration Strip, then remove it

- Putting the test strip and installing it in the device

- Sterilization of the finger from which the blood is to be drawn with sterile materials, preferably the index finger Pricking the tip of the finger with the needle drill provided with the device -

- After the blood comes out from the finger, a drop of blood is placed on the measuring tape attached to the device.

- The device will show a (specific) sound, then the device will start counting down from (60 seconds) to (one second), so that the measurement result will appear on the device's screen with a unit of measurement (millimole / liter)
Recording: The reading shown by the device after measurement is recorded for each laboratory runner in the registration form.

- The test of the a-clackogenic auxiliary ability (Muhammad Ali Al-Qatt: 1999, p. 27)

Vertical jump test for (60) seconds.

The purpose of the test: To test the clackogenic anoxic capacity.

Performance specifications: In this test, the laboratory performs the vertical jump upwards as long as it can for a period of (60) seconds, using a constant voltage measuring device. A period of (60) seconds, so that the knees are bent (90 degrees) and the hands are extended along the side of the thighs.

Recording: the ability is calculated by the following equation:

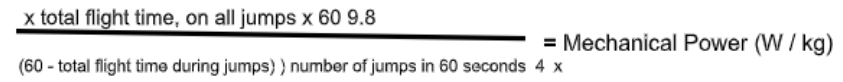

-The name of the test: - The high jump shot test - Imama (Diaa Al-Khayyat and Nawfal Muhammad Al-Hayali: 2001, p.508)

Objective of the test: - High jump shot accuracy - forward - Method of performance: The player stands behind the starting line (depending on the aiming hand) and holds the ball, the player begins to take 2-3 steps and then leads the shot with a high jump to square (1) then to (2) then to (3) then (4) The performance is repeated 3 times, i.e., (12) balls three of them into one of the four squares, taking no more than three steps.

Tools: 20 balls.

- Method of scoring: A point is calculated from the ball entering the square for the shot, zero is counted for the shot outside the square. The result of a shot from which the player moves more than three steps is not considered.

\section{: Exploration Experience}

The researcher conducted the pilot experiment on a sample of (4) players on Saturday, 5/30/2020, in the closed hall of the Specialized Schools of Handball of the Ministry of Youth and Sports / Baghdad Governorate. The exploratory experience of the researcher helped to identify: The validity of the devices and tools used in the research. The time it takes to run the tests. 
To determine the difficulties that the researcher may encounter when performing the main tests.

. Exercises of maximum physical effort according to the anaerobic threshold -

\section{Main experience:}

:Before tests

The researcher conducted the pre-exams on Monday $1 / 6 / 2020$ in the closed hall of the Specialized Schools of Handball of the Ministry of Youth and Sports / Baghdad Governorate

:Key Experience

The exercises began on 6/3/2020 until 2/8/2020

Duration of exercises placed in weeks: (8) weeks

The total number of training units: (24) training units

Number of weekly training units: (3) units

Weekly training days: (Saturday - Monday - Wednesday)

Training method used: high intensity interval training

Training intensity used: $(80-90 \%)$

: after Tests
The researcher conducted the post tests in the closed hall of the Specialized Schools of Handball of the Ministry of Youth and Sports / Baghdad Governorate on Wednesday $5 / 8 / 2020$ (after completing the proposed exercises with the same steps and conditions in which the tests were conducted.

\section{:Statistical means}

The researcher used the statistical package (SPSS) to find the appropriate statistical treatments.

\section{RESULT AND DISCUSSION:}

Presentation, analysis and discussion of results:

Presenting, analyzing and discussing the results of the experimental and control groups regarding the studied variables.

Presentation and analysis of the results of the differences between the pre and post tests of the experimental group in the researched variables.

Table (3)

The difference of the arithmetic mean, its standard deviation, the value $(\mathrm{t})$, and the significance of the differences between the results of the Before and after tests of the control group in the variables under consideratio

\begin{tabular}{|c|c|c|c|c|c|c|c|c|}
\hline \multirow{2}{*}{$\begin{array}{l}\text { Indication of } \\
\text { differences }\end{array}$} & \multirow{2}{*}{$\begin{array}{l}\text { Indication } \\
\text { level }\end{array}$} & \multirow{2}{*}{$\begin{array}{l}\text { The computed } \\
\text { t value }\end{array}$} & \multicolumn{2}{|l|}{ Test after } & \multicolumn{2}{|c|}{ Test before } & \multirow{2}{*}{$\begin{array}{l}\text { Measruing } \\
\text { unit }\end{array}$} & \multirow[t]{2}{*}{ The exams } \\
\hline & & & $\begin{array}{l}\text { standard } \\
\text { deviation }\end{array}$ & $\begin{array}{l}\text { Arithmetic } \\
\text { mean }\end{array}$ & $\begin{array}{l}\text { standard } \\
\text { deviation }\end{array}$ & $\begin{array}{l}\text { Arithmetic } \\
\text { mean }\end{array}$ & & \\
\hline moral & 0,003 & 2,243 & 177,23 & 4,91 & 325,2 & 4,55 & $\mathrm{M} / \mathrm{cm}$ & $\begin{array}{l}\text { The explosive } \\
\text { power of the arms }\end{array}$ \\
\hline moral & 0,001 & 2,07 & 0,44 & 2,46 & 0,05 & 2,21 & $\mathrm{M} / \mathrm{cm}$ & $\begin{array}{l}\text { The explosive } \\
\text { power of the two } \\
\text { men }\end{array}$ \\
\hline moral & 0.000 & 3,98 & $\mathbf{0 , 8 7}$ & 13,01 & 0,43 & 12,66 & Mmol / liter & $\begin{array}{l}\text { (LA) } \\
\text { concentration } \\
\text { after effort }\end{array}$ \\
\hline moral & 0,002 & 4,32 & 0,54 & 4,98 & 0,48 & 4,70 & Watt / kg & $\begin{array}{l}\text { Clackogenic } \\
\text { auxiliary capacity }\end{array}$ \\
\hline moral & 0,001 & 2,06 & 0,42 & 5,94 & $\mathbf{0 , 4 7}$ & 4,73 & Degree & \begin{tabular}{ll}
\multicolumn{2}{l}{ Measure accuracy } \\
of aiming & from \\
jumping & high \\
forward &
\end{tabular} \\
\hline
\end{tabular}

Significance below the level of significance of $\leq(0.05)$ and before the degree of freedom $(8-1=7)$

Presenting and analyzing the results of the differences between the pre and post tests of the control group in the researched variables

Table (4) 
The difference of the arithmetic mean, its standard deviation, the value (t), and the significance of the differences between the results of the pre and post tests of the experimental group in the variables under investigation

\begin{tabular}{|c|c|c|c|c|c|c|c|c|}
\hline \multirow{2}{*}{$\begin{array}{l}\text { Indication of } \\
\text { differences }\end{array}$} & \multirow{2}{*}{$\begin{array}{l}\text { Indication } \\
\text { level }\end{array}$} & \multirow{2}{*}{$\begin{array}{l}\text { The computed } t \\
\text { value }\end{array}$} & \multicolumn{2}{|l|}{ Test after } & \multicolumn{2}{|c|}{ Test before } & \multirow[t]{2}{*}{ measruing unit } & \multirow[t]{2}{*}{ The exams } \\
\hline & & & $\begin{array}{l}\text { standard } \\
\text { deviation }\end{array}$ & $\begin{array}{l}\text { Arithmetic } \\
\text { mean }\end{array}$ & $\begin{array}{l}\text { standard } \\
\text { deviation }\end{array}$ & $\begin{array}{l}\text { Arithmetic } \\
\text { mean }\end{array}$ & & \\
\hline moral & 0.005 & 5,692 & 330,04 & 5,93 & 429,6 & 5,78 & $\mathrm{M} / \mathrm{cm}$ & $\begin{array}{l}\text { The explosive } \\
\text { power of the arms }\end{array}$ \\
\hline moral & 0,000 & 3,78 & 0,51 & 3,02 & 0,48 & 2,81 & $\mathrm{M} / \mathrm{cm}$ & $\begin{array}{l}\text { The explosive } \\
\text { power of the two } \\
\text { men }\end{array}$ \\
\hline moral & 0,000 & 4,84 & 0,54 & 12,56 & 0,23 & 12,36 & Mmol / liter & $\begin{array}{l}\text { (LA) } \\
\text { concentration } \\
\text { after effort }\end{array}$ \\
\hline moral & 0,002 & 3,85 & 0,89 & 6.4 & 0,67 & 5,81 & Watt / kg & $\begin{array}{l}\text { Clackogenic } \\
\text { auxiliary capacity }\end{array}$ \\
\hline moral & 0,000 & 4,06 & 0,42 & 5,99 & 0,63 & 5,61 & Degree & $\begin{array}{lr}\text { Measure } & \\
\text { accuracy } & \text { of } \\
\text { aiming } & \text { from } \\
\text { jumping } & \text { high } \\
\text { forward } & \end{array}$ \\
\hline
\end{tabular}

Significant below the level of significance of $\leq(0.05)$ and before the degree of freedom $(7-1=6)$

Presenting the results of the differences between the two post-tests of the control and experimental groups in the studied variables.

Table (5)

And the value of $(t)$, the level of error, and the significance of the differences between the results of the post-test for the control and experimental groups in the variables under investigation

\begin{tabular}{|c|c|c|c|c|c|c|c|c|}
\hline \multirow{2}{*}{$\begin{array}{l}\text { Indication of } \\
\text { differences }\end{array}$} & \multirow{2}{*}{$\begin{array}{l}\text { Indication } \\
\text { level }\end{array}$} & \multirow{2}{*}{$\begin{array}{l}\text { The computed } \\
\text { t value }\end{array}$} & \multicolumn{2}{|c|}{ Experimental group } & \multicolumn{2}{|c|}{ Control group } & \multirow{2}{*}{$\begin{array}{l}\text { Measruin } \\
\text { g unit }\end{array}$} & \multirow[t]{2}{*}{ The exams } \\
\hline & & & $\begin{array}{l}\text { standard } \\
\text { deviation }\end{array}$ & $\begin{array}{l}\text { Arithmetic } \\
\text { mean }\end{array}$ & $\begin{array}{l}\text { standard } \\
\text { deviation }\end{array}$ & $\begin{array}{l}\text { Arithmetic } \\
\text { mean }\end{array}$ & & \\
\hline moral & 0,002 & 4,44 & 0,87 & 6,05 & 330,06 & 4,98 & $\mathrm{M} / \mathrm{cm}$ & $\begin{array}{l}\text { The explosive power of } \\
\text { the arms }\end{array}$ \\
\hline moral & 0,000 & 4,15 & 0,57 & 3.11 & 0,48 & 2,54 & $\mathrm{M} / \mathrm{cm}$ & $\begin{array}{l}\text { The explosive power of } \\
\text { the two men }\end{array}$ \\
\hline moral & 0,002 & 3,87 & 0,43 & 14,840 & 0,87 & 13,420 & $\begin{array}{l}\text { Mmol / } \\
\text { liter }\end{array}$ & $\begin{array}{l}\text { (LA) concentration after } \\
\text { effort }\end{array}$ \\
\hline moral & 0,001 & 2,87 & 0,23 & 6,08 & 0,65 & 5,01 & Watt / kg & $\begin{array}{l}\text { Clackogenic auxiliary } \\
\text { capacity }\end{array}$ \\
\hline
\end{tabular}




\begin{tabular}{|l|l|l|l|l|l|l|l|l|}
\hline moral & 0,001 & 2,59 & 0,43 & 7,05 & 0,42 & 6,02 & $\begin{array}{l}\text { Degree } \\
\text { aiming from jumping high } \\
\text { forward }\end{array}$ \\
\hline
\end{tabular}

Significance at a level of significance $(0.05)$ and before a degree of freedom $(7+7-2=12)$

The results showed a significant difference between the pre and post tests of the experimental research sample for the research variables and it was a remarkable development for the post test, and the researcher attributes that significant difference to the preparation of maximum physical effort exercises according to the anaerobic threshold in developing the explosive ability and the skill of shooting by jumping high - forward, to the effect of physical exercises Which was used in the training units, represented by medical balls for the arms, jumping exercises for the front, as well as over the boxes, had an effective role in this development that took place (Kay, D: 1993, p33). Also, diversification in the use of heavy rope exercises led to the elimination of boredom, suspense and effort by the

players and pushing them seriously towards the best performance because the various exercises make the player excited to train and stimulate different muscle groups according to the type of exercise. (Suhad Qasim al-Musawi. Diana Hussein.2020.p470)

The imprinting and adaptation that occurred to the handball players through the use of exercises in the training units, which led to the development of the devices' ability to withstand the effort placed on them, especially the energy supply outlets, with regard to the concentration of (LA) acid after the effort, which occurred from the physiological imprinting of the muscle in the possibility of retaining it For a period of time in the muscle, without the speed of its access to the blood, and that is why its quantity differed in the post-test, in addition to that, obtaining (ATP) particles from the anaerobic glycolytic system (LA) is small, as rebuilding 3 moles (ATP) needs an amount of 180 Gram of glycogen (Samia Khalil Muhammad: 2008, p. 27)

The effect of training, which contributed to the increase in claogenic ability, whether it was muscle stimulation or liver stimulation, that clacogen stored in muscles and liver is one of the best fuel for high-intensity sports (Nadim Al-Masry: 2001, p. 140), and the researcher attributes these differences to the use of high intensity in The anaerobic exercises and when the oxygen level is low, which leads to an increase in the production of lactic acid in the blood, the increase in the production of lactic acid in the blood depends on the type and intensity of the muscular work performed by the athlete. If the muscular work is of high intensity and is carried out in conditions of insufficient oxygenation, the accumulation and accumulation of lactic acid in the blood increases (Jamal Sabri Faraj: 2012, p. 298) Correction is the final movement for all skill and planning efforts, as well as hitting the target enhances the players' self-confidence, inspires enthusiasm in them and drives the players To make great effort and cooperate with colleagues to win (Vialla Lesstirs delaile: 1990, p132)

\section{CONCLUSIONS:}

-The results showed a significant superiority between the pre and post measurement in the anaerobic threshold in developing the explosive power of the experimental group and in favor of the post measurement.

- The results showed a significant superiority between the pre and post measurement in (the skill of shooting high jumping forward) for the players of the experimental group and in favor of the post measurement.

- The experimental group surpassed the control group in the post measurement of the studied variables

And for the benefit of the experimental group.

\section{ENDORSEMENT:}

- Preparation of training programs with maximum physical effort according to the anaerobic threshold in developing explosive ability and in proportion to the physical and skill capabilities of handball.

- Conducting similar studies on other groups in order to develop the physical and skill abilities in handball. 


\section{REFERENCES:}

- Jamal Sabri Faraj: Strength, Power and Modern Sports Training, Amman, Degla House, 2012.

- Samia Khalil Muhammad; Principles of Mathematical Physiology, 1st Edition: (Baghdad, Baghdad, Nasher Printing Press, 2008), p. 27.

- Diaa Al-Khayyat and Nawfal Muhammad Al-Hayali: Handball, Mosul, Dar AlKutub for Printing and Publishing, 2001.

- Muhammad Hassan Allawi and Muhammad Nasreddin Radwan; Kinetic Performance Test, 3rd Edition: (Cairo, Dar Al Fikr Al Arabi, 1994), p.84.

- Muhammad Ali Al-Qat. Sports Training Members Jobs - An Applied Introduction, Cairo: Arab Thought House, 1999, p. 27.

- Nadim Al-Masry; Sports, food before the doctor, and medicine: (Damascus, Dar Al-Fikr, 2001), p. 140.

- Hazaa Muhammad Hazaa: Laboratory Experiments in Physical Exhaustion Positions, King Saud University, Deanship of Library Affairs, 1992.

Kay, D: Long Jump , London British Amateur Athletic Bound, 1993. -

-Vialla Lesstirs delaile:Hand BallDicetion tehingne. National commison pedugogic,13,1999.

- Suhad Qasim al-Musawi. Diana Hussein. THE EFFECT OF USING SOME PHYSICALEXERCISES WITH HEAVY ROPES TODEVELOP THE DEVELOPMENT OF THEEXPLOSIVE ABILITY OF THE ARMS ANDLEGS AND THE ACCURACY OF THEOVERWHELMING PERFORMANCE OF

VOLLEYBALL. International Journal of Research in Social Sciences and Humanities 2020.p470.)

\section{ANNEX (1)}

A model of the unit training in the first week

\begin{tabular}{|c|c|c|c|c|c|c|c|}
\hline Notes & $\begin{array}{l}\text { Rest between } \\
\text { groups }\end{array}$ & Totals & $\begin{array}{l}\text { Rest between } \\
\text { repetitions }\end{array}$ & Training volume & Intensity & Exercises used & sequence \\
\hline $\begin{array}{l}15 \times 12=3 \text { minutes } \\
45 \times 12=9 \text { minutes } \\
\text { Rest between } \\
\text { groups of } 3 \text { minutes } \\
\text { grand total }=15 \\
\text { minutes }\end{array}$ & seconds 60 & 3 & 45 seconds & 15 second $\mathrm{x} 4$ & & $\begin{array}{l}\text { The player receives from } \\
\text { the coach, and after } \\
\text { receiving, he takes three } \\
\text { steps outside the 9-meter } \\
\text { area to shoot at the goal }\end{array}$ & 1 \\
\hline $\begin{array}{l}\begin{array}{l}10 \times 12=2 \\
\text { minutes }\end{array} \\
45 \times 12=9 \text { minutes } \\
\begin{array}{l}\text { Rest between } \\
\text { groups of } 3 \text { minutes } \\
\text { grand total = } 14 \\
\text { minutes }\end{array}\end{array}$ & seconds 60 & 3 & 45 seconds & 10 second $\mathrm{x} 4$ & $80 \%$ & $\begin{array}{l}\text { From a sitting position, the } \\
\text { player performs a } 2 \mathrm{~kg} \text { fold } \\
\text { ball, and then the player } \\
\text { raises and lowers the ball } \\
\text { in front and upward. }\end{array}$ & 2 \\
\hline $\begin{array}{l}10 \times 12=2 \\
\text { minutes } \\
45 \times 12=9 \text { minutes }\end{array}$ & seconds 60 & 3 & 45 seconds & 10 second $\mathrm{x} 4$ & & $\begin{array}{l}\text { Double jumping on } 8 \\
\text { hurdles of } 80 \mathrm{~cm} \text { high }\end{array}$ & 3 \\
\hline
\end{tabular}


International Journal of Research in Social Sciences and Humanities

(IJRSSH) 2020, Vol. No. 10, Issue No. IV, Oct-Dec http://www.ijrssh.com

e-ISSN: 2249-4642, p-ISSN: 2454-4671

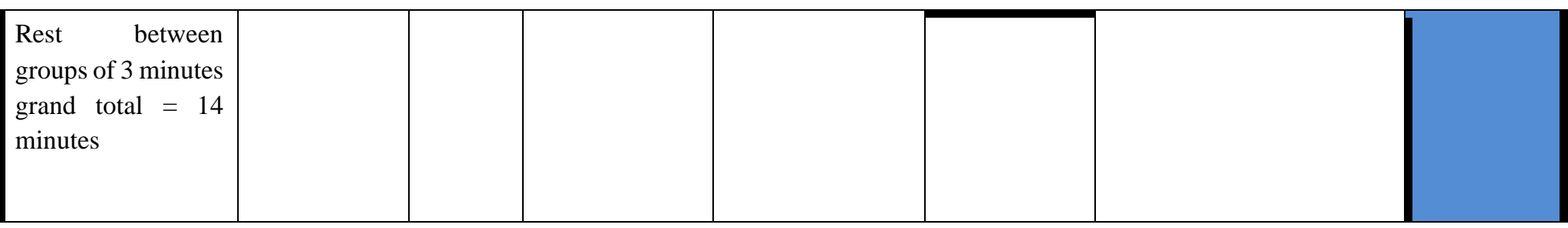

